\title{
Article \\ SIRT1-Dependent Upregulation of BDNF in Human Microglia Challenged with A $\beta$ : An Early but Transient Response Rescued by Melatonin
}

\author{
Grazia Ilaria Caruso ${ }^{\dagger}$, Simona Federica Spampinato (D, Giuseppe Costantino $\ddagger$, Sara Merlo $*, \S^{(D)}$ and \\ Maria Angela Sortino *, § (D)
}

check for

updates

Citation: Caruso, G.I.; Spampinato, S.F.; Costantino, G.; Merlo, S.; Sortino, M.A. SIRT1-Dependent Upregulation of BDNF in Human Microglia Challenged with $A \beta$ : An Early but Transient Response Rescued by Melatonin. Biomedicines 2021, 9, 466. https://doi.org/10.3390/

biomedicines 9050466

Academic Editor: Lorenzo Falsetti

Received: 26 March 2021

Accepted: 21 April 2021

Published: 24 April 2021

Publisher's Note: MDPI stays neutral with regard to jurisdictional claims in published maps and institutional affiliations.

Copyright: (c) 2021 by the authors. Licensee MDPI, Basel, Switzerland This article is an open access article distributed under the terms and conditions of the Creative Commons Attribution (CC BY) license (https:// creativecommons.org/licenses/by/ $4.0 /)$.
Department of Biomedical and Biotechnological Sciences, Section of Pharmacology, University of Catania, Via Santa Sofia 97, 95123 Catania, Italy; grazia.caruso@outlook.it (G.I.C.); simona_spampinato@hotmail.com (S.F.S.); giuseppe.costantino@unifg.it (G.C.)

* Correspondence: sara_merlo@hotmail.com (S.M.); msortino@unict.it (M.A.S.)

+ Ph.D. Program in Biotechnologies, Department of Biomedical and Biotechnological Sciences, University of Catania, 95123 Catania, Italy.

$\ddagger$ Ph.D. Program in Neuroscience and Education, DISCUM, University of Foggia, 71121 Foggia, Italy.

$\S$ Co-last authors that contributed equally to the supervision of this work.

\begin{abstract}
Microglia represent a first-line defense in the brain. However, in pathological conditions such as Alzheimer's disease (AD), a pro-inflammatory switch may occur, leading to loss of protective functions. Using the human microglial cell line HMC3, we showed that exposure to low concentrations of $\beta$-amyloid peptide 1-42 (A $\beta 42 ; 0.2 \mu \mathrm{M})$ initially $(6 \mathrm{~h})$ upregulated anti-inflammatory markers interleukin (IL)-4, IL-13, and brain-derived neurotrophic factor (BDNF). BDNF increase was prevented by selective inhibition of SIRT1 with EX527 $(2 \mu \mathrm{M})$. Accordingly, these early effects were accompanied by a significant A $\beta 42$-induced increase of SIRT1 expression, nuclear localization, and activity. SIRT1 modulation involved adenosine monophosphate-regulated kinase (AMPK), which was promptly (30 min) phosphorylated by A $\beta 42$, while the AMPK inhibitor BML-275 $(2 \mu \mathrm{M})$ attenuated A $\beta 42$-induced SIRT1 increase. Initially observed microglial responses appeared transient, as microglial features changed when exposure to $\mathrm{A} \beta 42$ was prolonged $(0.2 \mu \mathrm{M}$ for $72 \mathrm{~h})$. While SIRT1 and BDNF levels were reduced, the expression of inflammatory markers IL- $1 \beta$ and tumor necrosis factor (TNF)- $\alpha$ increased. This coincided with a rise in NF-kB nuclear localization. The effects of melatonin $(1 \mu \mathrm{M})$ on prolonged microglial exposure to $A \beta 42$ were analyzed for their protective potential. Melatonin was able to prolong SIRT1 and BDNF upregulation, as well as to prevent NF-kB nuclear translocation and acetylation. These effects were sensitive to the melatonin receptor antagonist, luzindole $(25 \mu \mathrm{M})$. In conclusion, our data define an early microglial defensive response to $\mathrm{A} \beta 42$, featuring SIRT1-mediated BDNF upregulation that can be exogenously modulated by melatonin, thus identifying an important target for neuroprotection.
\end{abstract}

Keywords: Alzheimer's disease; HMC3 human microglia; inflammation; microglial switch; NF-kB; Silent Information Regulator 2 homolog 1; brain-derived neurotrophic factor

\section{Introduction}

Alzheimer's disease (AD) is a progressive neurodegenerative disorder affecting primarily the elderly. A salient feature of $\mathrm{AD}$ is that it develops slowly over the years, remaining asymptomatic for up to two decades before diagnosis is possible [1,2]. By this time, neurodegeneration is so advanced that chances for treatment are reduced, accounting at least in part for current failure to develop effective disease-modifying therapies $[1,3]$.

From a molecular point of view, hallmarks of AD are the increased brain levels of the beta amyloid peptide $(\mathrm{A} \beta)$ and phosphorylated tau protein, which respectively aggregate into extracellular plaques and intracellular tangles [4-7]. According to the amyloid cascade 
hypothesis, initial accumulation of the aggregation-prone 42 amino acid-long isoform of $\mathrm{A} \beta(\mathrm{A} \beta 42)$ is the result of an imbalance between its production and/or clearance, leading to abnormally high concentrations of oligomers that hold potential for neurotoxicity upon chronic exposure [5]. A $\beta$ can directly interact with neuronal surface molecules, damage the cell membrane, and be internalized with ensuing oxidative stress [8]. Interestingly, however, glial cells can respond to rising concentrations of $A \beta$ oligomers activating to oppose its buildup and its neurotoxicity. Microglia, in particular, interact with $A \beta$ through a variety of receptors and are the main effectors of its clearance, exerting an initial anti-inflammatory response [9-12]. However, the clearing and neuroprotective functions of microglia may become insufficient upon excessive $\mathrm{A} \beta$ buildup, triggering a pro-inflammatory phenotypic switch [13]. In agreement, data from both $\mathrm{AD}$ patients and animal studies reported an increased expression of neuroinflammatory cytokines with disease progression, which coincided with a significant reduction of BDNF levels in cognition-related brain structures and in serum [14]. On these bases, targeting microglia to enhance/prolong their beneficial functions and halt/delay pro-inflammatory polarization has been proposed to represent a successful strategy $[15,16]$.

Among candidate effectors for neuroprotection against neurodegenerative diseases, including AD, is Silent Information Regulator 2 homolog 1 (SIRT1) [17-20]. SIRT1 is an $\mathrm{NAD}^{+}$-dependent deacetylase that modulates gene expression by deacetylation of histones and transcription factors. Among its targets is NF-kB, accounting for the anti-inflammatory actions of the enzyme [21,22]. In particular, SIRT1 has been shown to affect several processes in the pathogenesis of $\mathrm{AD}$, from $\mathrm{A} \beta$ synthesis to tau toxicity, and declines in its levels have been suggested to mirror disease progression [23-25].

An interesting candidate activator of SIRT1 is melatonin, an endogenous neurohormone shown to be pleiotropic and neuroprotective in neurodegenerative conditions [26] including AD [27], Parkinson's disease [28], hypoxia/ischemia [29], and spinal cord injury [30]. Animal and human studies showed that the use of melatonin is safe in shortand long-term treatments. Only mild and no serious adverse effects have in fact been reported so far [31]. Melatonin is able to exert neuroprotection through different cellular mechanisms, including activation of antiapoptotic pathways, upregulation of anti-oxidant enzymes, and inhibition of pro-inflammatory signaling [26,32]. The hormone mainly acts through cell membrane G protein-coupled receptors, MT1 and MT2 [33,34], both widely distributed in different brain areas and expressed by both neuronal and glial cells [35]. In addition, intracellular binding sites have been reported, namely the quinone reductase enzyme MT3 [36] and the retinoic acid-related orphan receptors RORs [37]. Non-receptormediated actions reported for melatonin include the direct detoxification of reactive oxygen and nitrogen species [38]. In AD, melatonin-mediated neuroprotective mechanisms include anti-amyloidogenic actions [39,40], synaptic stabilization [41], and promotion of neurogenesis [42]. Clinical studies are currently underway to determine the potential of melatonin administration against sleep alterations and related decline in cognitive functions in $\mathrm{AD}$, with so far positive results [43].

Based on these premises, and moving from our previous work showing the early contribution of microglia to neuroprotection [11], we here aimed to characterize the time course of beneficial microglial responses to low concentrations of $A \beta$, using an in vitro system to mimic the very initial events in AD development. For this purpose, we used the human microglial cell line HMC3. Furthermore, we evaluated the involvement of SIRT1 and the ability of melatonin to target SIRT1 in order to enhance microglial antiinflammatory functions, hindering the pro-inflammatory switch.

\section{Materials and Methods}

\subsection{Drugs and Reagents}

Amyloid $\beta$ peptide 1-42 (A $\beta 42$ ) from Innovagen (Lund, Sweden) was prepared according to the protocol previously used in our lab [44]. Briefly, A $\beta$ was dissolved in dimethylsulfoxide (DMSO; Sigma-Merck, Darmstadt, Germany) as a 5 mM stock, subse- 
quently diluted to $100 \mu \mathrm{M}$ in a culture medium, and enriched in oligomers by aggregation at RT for $24 \mathrm{~h}$, followed by at least two freeze-thaw cycles prior to use. Melatonin, EX527 (Santa Cruz Biotechnologies, Santa Cruz, CA, USA), and BML-275 (Enzo Life Sciences Inc., Farmingdale, NY, USA) were dissolved in DMSO as $10 \mathrm{mM}$ stocks and further diluted in a culture medium for experiments. Both EX527 and BML-275 were always added $15 \mathrm{~min}$ before other drugs. Luzindole (Tocris, Bristol, UK) was dissolved in DMSO as $50 \mathrm{mM}$ stock and further diluted in culture medium for experiments, where it was always added $30 \mathrm{~min}$ before other drugs. Golgi inhibitor brefeldin-A (Thermofisher Scientific, Waltham, MA, USA) was dissolved in DMSO as a $10 \mathrm{mg} / \mathrm{mL}$ stock and added during the last $3 \mathrm{~h}$ of treatment.

\subsection{Cell Cultures}

The HMC3 human microglial cell line (ATTC, LGC Standards, Manassas, VA, USA) was grown in Eagle's Minimum Essential Medium (EMEM; Thermofisher Scientific, Waltham, MA, USA) supplemented with $10 \%$ fetal bovine serum (FBS; Thermofisher Scientific,Waltham, MA, USA) and penicillin $(100 \mathrm{U} / \mathrm{mL}) /$ streptomycin $(100 \mu \mathrm{g} / \mathrm{mL})$ at 37 ${ }^{\circ} \mathrm{C}$ and in a $5 \% \mathrm{CO}_{2}$ atmosphere. Based on experimental needs, cells were plated with the following densities: $800 \mathrm{k}$ cells/well in six-well plates, $15 \mathrm{k}$ cells/well in 96-well plates (all plastic from Falcon, Milan, Italy), or $8 \mathrm{k}$ cells/well in eight-well microslides (Ibidi, Gräfelfing, Germany). For morphological observation, cells were stained with the fluorescent dye $\mathrm{FM}^{\circledR} 1-43$ (5 $\mu \mathrm{M}$ for 15 min; Thermofisher Scientific, Waltham, MA, USA).

\subsection{Quantitative Real-Time Polymerase Chain Reaction}

Cells were collected and total RNA extracted using the RNeasy Plus Mini Kit (Qiagen, Milan, Italy). RNA concentration was determined using Nanodrop spectrophotometer ND-1000 (Thermofisher Scientific, Waltham, MA, USA), and $2 \mu \mathrm{g}$ of RNA were reverse transcribed using Superscript-VILO kit (Thermofisher Scientific, Waltham, MA, USA) according to the manufacturer's instructions. Quantitative real-time PCR (qRT-PCR) was performed on a 1:300 dilution of the reverse transcription reaction per sample, using the Rotor-Gene Q and Qiagen QuantiNova SYBR Green Real Time-PCR Kit. Primers are listed in Table 1 and were all from Qiagen. RPLP0 was used as the endogenous control. Melting curve analysis confirmed the specificity of the amplified products. Data were analyzed applying the $\Delta \Delta \mathrm{Ct}$ method and expressed as fold change vs. control.

Table 1. Primers used for qRT-PCR.

\begin{tabular}{ccc}
\hline Gene & \multicolumn{1}{c}{ Primer } & Cat. No. \\
\hline BDNF & Hs_BDNF_1_SG QuantiTect Primer Assay & QT00235368 \\
IL-13 & Hs_IL13_1_SG QuantiTect Primer Assay & QT00000511 \\
IL-4 & Hs_IL4_1_SG QuantiTect Primer Assay & QT00012565 \\
TNF $\alpha$ & Hs_TNF_1_SG QuantiTect Primer Assay & QT00029162 \\
IL-1 $\beta$ & Hs_IL1B_1_SG QuantiTect Primer Assay & QT00021385 \\
RPLP0 & Hs_RPLP0_1_SG QuantiTect Primer Assay & QT00075012 \\
\hline
\end{tabular}

\subsection{Enzyme-Linked Immunosorbent Assay (ELISA)}

Levels of BDNF in medium from HMC3 cells plated in 96-well microplates were determined using the Biosensis ${ }^{\circledR}$ BDNF RapidTM ELISA kit (Biosensis Pty Ltd., Thebarton, SA, Australia), strictly following the manufacturer's instructions. Absorbance at $450 \mathrm{~nm}$ was measured with a VarioskanTM Flash Multimode Reader.

\subsection{Western Blot}

Cells were collected and lysed in M-PER ${ }^{\circledR}$ Mammalian Protein Extraction Reagent (Thermofisher Scientific, Waltham, MA, USA) supplemented with anti-protease and antiphosphatase cocktails (Sigma-Merck, Darmstadt, Germany). Samples were sonicated, and centrifuged at high speed for $5 \mathrm{~min}$ at $4{ }^{\circ} \mathrm{C}$, and protein concentration was determined by a Bradford reagent (Sigma-Merck, Darmstadt, Germany), according to the manufacturer's 
instructions. Absorbance was measured with a VarioskanTM Flash Multimode Reader. Nuclear and cytoplasmic fractions were extracted using the Subcellular Protein Fractionation Kit for Cultured Cells (Thermofisher Scientific, Waltham, MA, USA), according to the manufacturer's instructions. Sodium dodecyl sulfate-poly-acrylamide gel electrophoresis (SDS-PAGE) was performed by loading equal amounts of protein extracts per experiment on pre-cast "any-kDa" or 4-20\% gradient gels (Bio-Rad, Hercules, CA, USA) followed by transfer to nitrocellulose membrane (Hybond ECL, Amersham Biosciences Europe $\mathrm{GmbH}$, Milan, Italy) using a Transblot semidry transfer cell (Bio-Rad, Hercules, CA, USA). Membranes were blocked with a Blocker FL Fluorescent Blocking buffer (Thermofisher Scientific, Waltham, MA, USA) and incubated with primary antibodies overnight at $4{ }^{\circ} \mathrm{C}$. The primary antibodies used were mouse anti-BDNF (1:900; Thermofisher Scientific, Waltham, MA, USA, Cat. No. MA5-34960), rabbit anti-SIRT1(H300) (1:400; Santa Cruz Biotechnologies, Santa Cruz, CA, USA, Cat. No. sc-15404), rabbit anti-NF-kBp65 (1:400; Thermofisher Scientific, Waltham, MA, USA, Cat. No. PA1-186), rabbit anti- $\beta$-actin (1:5000; Sigma-Merck, Darmstadt, Germany, Cat. No. A2066), mouse anti-glyceraldehyde 3-phosphate dehydrogenase (GAPDH) (1:5000; Millipore, Billerica, MA, USA, Cat. No. MAB374), and mouse anti-lamin B1 (1:1000; Santa Cruz Biotechnologies, Santa Cruz, CA, USA, Cat. No. sc-365214). Membranes were then washed and exposed to appropriate secondary antibodies for $45 \mathrm{~min}$ at RT as follows: AlexaFluor (AF) 647-conjugated anti-rabbit (1:2000; Thermofisher Scientific, Waltham, MA, USA), AF488 Plus-conjugated anti-rabbit (1:2000; Thermofisher Scientific, Waltham, MA, USA), and AF488 Plus-conjugated anti-mouse (1:5000; Thermofisher Scientific, Waltham, MA, USA). The detection of specific bands was carried out using the iBright FL1500 Imaging System (Thermofisher Scientific, Waltham, MA, USA). Band intensity was analyzed using the ImageJ software, developed by the National Institutes of Health (NIH) and in the public domain.

\subsection{Immunoprecipitation (IP) \& SIRT1 Activity Assay}

Cell lysates were obtained as described in the Western blot section above. An amount of $350 \mu \mathrm{g}$ of extracted proteins was diluted in a final volume of $500 \mu \mathrm{L}$ with M-PER lysis buffer and incubated with $2 \mu \mathrm{g}$ of rabbit anti-SIRT1(H300) primary antibody (1:400; Santa Cruz Biotechnologies, Santa Cruz, CA, USA, Cat. No. sc-15404) for 24 h at $4{ }^{\circ} \mathrm{C}$. Next, $20 \mu \mathrm{L}$ of Protein A/G PLUS-Agarose beads (Santa Cruz Biotechnologies, Santa Cruz, CA, USA, Sc-2002) were added, followed by incubation at $4{ }^{\circ} \mathrm{C}$ overnight. The mixture was centrifuged at $2500 \mathrm{rpm}$ for $5 \mathrm{~min}$ at $4{ }^{\circ} \mathrm{C}$. The supernatant was discarded, and the co-IP products were washed five times with PBS. After the final wash, the precipitates were resuspended in $30 \mu \mathrm{L}$ of assay buffer from the SIRT1 activity assay kit. Enzyme activity was assayed with SIRT1 Fluorometric Drug Discovery Kit (Enzo Life Sciences Inc., Farmingdale, NY, USA) according to the manufacturer's instructions.

\subsection{Immunocytochemistry}

Cells were fixed using InsideFix Solution (Miltenyi Biotec, Bologna, Italy) and incubated overnight at $4{ }^{\circ} \mathrm{C}$ with primary antibodies diluted in InsidePerm solution (Miltenyi, Bologna, Italy). The antibodies used were rabbit anti-SIRT1(H300) (1:400; Santa Cruz Biotechnologies, Santa Cruz, CA, USA, Cat. No. sc-15404) and rabbit anti-acetyl-NF-kB p65 (Lys310) (1:30; Cell Signaling, Danvers, MA, USA, Cat. No. 3045). After washing, cells were incubated with secondary antibodies, diluted in InsidePerm solution, for 45 min RT. The secondary antibodies used were AF488-anti-mouse (1:300; Thermofisher Scientific, Waltham, MA, USA) and AF488-anti-rabbit (1:300; Thermofisher Scientific, Waltham, MA, USA). After washing, slides were mounted with 4',6-diamidino-2-phenylindole (DAPI)containing mounting solution (Sigma-Merck, Darmstadt, Germany). Digital images were captured with a Zeiss Observer.Z1 microscope equipped with the Apotome.2 acquisition system (Zeiss, Oberkochen, Germany). The number of immunopositive cells with nuclear SIRT1 was determined by cell counting in at least five randomly selected fields/well. 


\subsection{Statistical Analysis}

All data were from three or more independent experiments run at least in triplicate. All experimental values are presented as the mean \pm SEM. Statistical analyses were performed, as appropriate, by Student's t-test and one- or two-way ANOVA followed by NewmanKeuls post-hoc test using GraphPad Prism Software (GraphPad Software, San Diego, CA, USA). $p<0.05$ was the criterion for statistical significance.

\section{Results}

\subsection{Microglia Respond to A $\beta 42$ with Transient SIRT1-Mediated BDNF Upregulation That Is Prolonged by Melatonin}

The ability of HMC3 microglia to upregulate BDNF in response to a short exposure to $A \beta 42$ was initially analyzed at the mRNA level by qRT-PCR. To this end, a low concentration of $0.2 \mu \mathrm{M}$ and a higher one of $2 \mu \mathrm{M}$ were initially tested. Results confirmed that only the lowest concentration $(0.2 \mu \mathrm{M})$ induced a significant short-term increase of BDNF mRNA at $6 \mathrm{~h}$ (fold change of $1.42 \pm 0.06 \mathrm{vs}$. C). In contrast, at the higher concentration of $2 \mu \mathrm{M}$, this effect was not present (fold change of $0.96 \pm 0.12 \mathrm{vs}$. C). Based on this preliminary evidence, subsequent experiments were carried out using $0.2 \mu \mathrm{M}$ of $\mathrm{A} \beta 42$.

Western blot analysis was then performed to determine protein levels of BDNF shortly after $\mathrm{A} \beta 42$ exposure. In these experiments, brefeldin $\mathrm{A}(5 \mu \mathrm{g} / \mathrm{mL})$ was added during the last $3 \mathrm{~h}$ of treatment, in order to prevent BDNF release and maximize its detection. Because of brefeldin A interference with the protein maturation pathway, a pre-pro isoform of BDNF of about $35 \mathrm{kDa}$ was detected. Microglia responded to $\mathrm{A} \beta 42$ with a significant increase in BDNF protein expression (Figure 1A). To examine the involvement of SIRT1 as a mediator of this effect, selective SIRT1 inhibitor EX527 $(5 \mu \mathrm{M})$ was added in combination with $\mathrm{A} \beta 42$. Results show that in these conditions, the BDNF increase was prevented (Figure 1A). Released BDNF levels were then assayed by ELISA in a conditioned medium at 6 and $24 \mathrm{~h}$ and after a prolonged exposure to $A \beta 42$ for $72 \mathrm{~h}$. While no effect was detected at $6 \mathrm{~h}$ (not shown), released BDNF levels were significantly augmented compared to control at $24 \mathrm{~h}$, an effect sensitive to EX527 (5 $\mu \mathrm{M}$; Figure 1B). When treatments were prolonged to $72 \mathrm{~h}$, microglia lost their ability to upregulate BDNF release in response to A $\beta 42$ (Figure 1C). Melatonin was thus tested in these conditions for its ability to contrast BDNF reduction. As shown in Figure 1C, in the presence of $1 \mu \mathrm{M}$ of melatonin, BDNF levels were still significantly higher than in control or A $\beta 42$-treated cells. Notably, melatonin's effect was prevented by the addition of EX527 $(5 \mu \mathrm{M})$ and of the mixed MT1/MT2 melatonin receptor antagonist luzindole $(25 \mu \mathrm{M})$, indicating a SIRT1-mediated and receptor-dependent action.

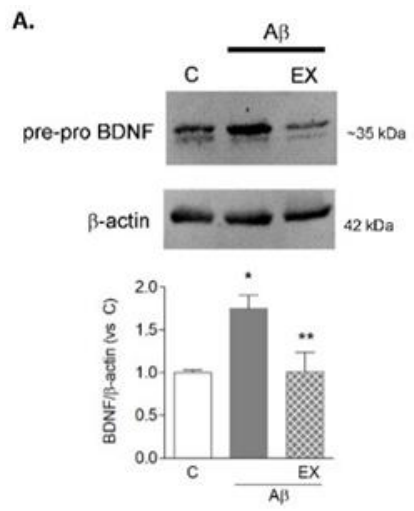

B.

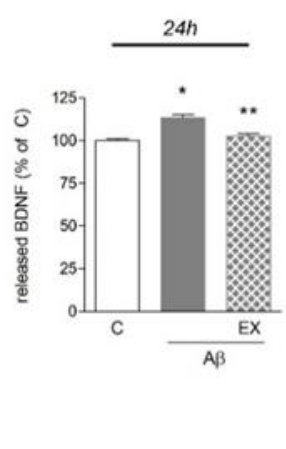

c.

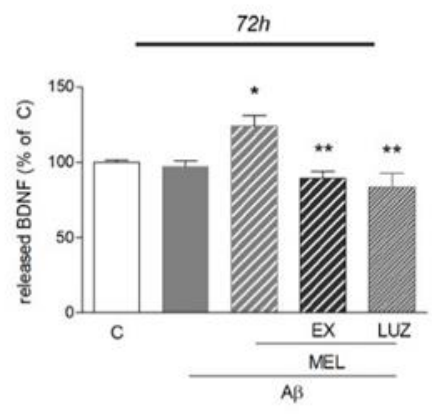

Figure 1. BDNF expression in HMC3 cells upon $A \beta 42$ exposure. In (A,B), cells were treated with $A \beta 42(0.2 \mu \mathrm{M})$ alone or in combination with SIRT1-selective inhibitor EX527 (EX, $5 \mu \mathrm{M})$. In (A), Western blot analysis of the intracellular content of BDNF at $6 \mathrm{~h}$ in the presence of brefeldin A $(5 \mu \mathrm{g} / \mathrm{mL})$. A representative blot is shown. ELISA determinations of released BDNF are reported at $24 \mathrm{~h}(\mathrm{~B})$ and $72 \mathrm{~h}(\mathbf{C})$. In panel $(\mathbf{C})$, melatonin (MEL, $1 \mu \mathrm{M})$ was added to $\mathrm{A} \beta 42$, alone or in combination with EX or luzindole (LUZ, $25 \mu \mathrm{M})$. Results are the mean \pm SEM of 3-5 independent experiments. ${ }^{*} p<0.05$ vs. C and ${ }^{* *} p<0.05$ vs. A $\beta$ (B) or vs. A $\beta+$ MEL (C) by one-way ANOVA followed by Newman Keuls test for significance. 


\subsection{Microglia Undergo a Pro-Inflammatory Switch Following Prolonged A $\beta 42$ Exposure}

To correlate transient BDNF induction after exposure to $A \beta 42$ with the state of polarization of human HMC3 microglial cells, gene expression of anti- and pro-inflammatory markers was evaluated by qRT-PCR at 3 and $72 \mathrm{~h}$. The anti-inflammatory markers interleukin (IL) 13 and IL4 were significantly induced shortly after exposure to A $\beta 42$ (Figure 2A), but were downregulated after prolonged treatment (Figure 2B). On the contrary, pro-inflammatory markers TNF $\alpha$ and IL1 $\beta$ were not modified after short exposure to A $\beta 42$ (Figure 2A), but were increased after prolonged exposure (Figure 2B). This is indicative of a microglial switch towards a pro-inflammatory phenotype after prolonged $A \beta 42$ exposure.

A.

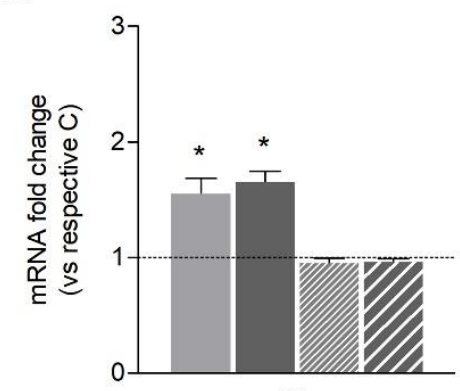

$3 h$
B.

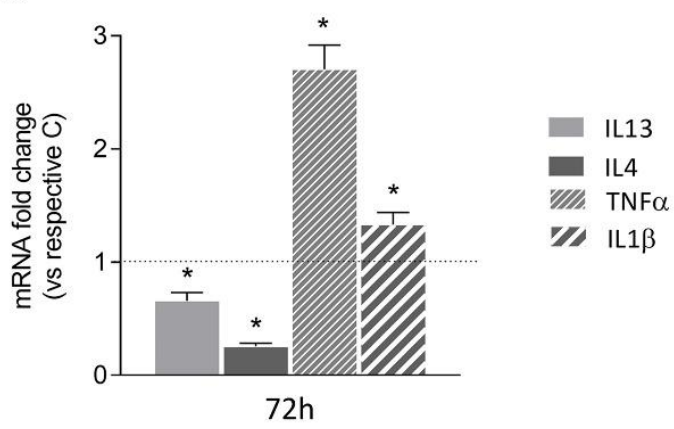

Figure 2. Time course of HMC3 microglial polarization. Cells were treated with $0.2 \mu \mathrm{M}$ of A $\beta 42.3 \mathrm{~h}(\mathrm{~A})$ or $72 \mathrm{~h}$ (B). Expression of anti-inflammatory (IL4 and IL13) and pro-inflammatory (TNF $\alpha$ and IL1 $\beta$ ) markers was investigated by qRT-PCR. Dotted lines indicate control values. Results are the mean \pm SEM of three independent experiments. ${ }^{*} p<0.05$ vs. respective control by Student's $t$-test for significance.

\subsection{Melatonin Prolongs Transient A 342 -Induced Upregulation of SIRT1 Activity and Expression}

Given the involvement of SIRT1 in mediating A $\beta 42$ - and melatonin-induced effects on BDNF levels, the time course of its expression was characterized in more detail. Based on the well-established interdependence of SIRT1 with the activation of the AMP-regulated protein kinase (AMPK) pathway, we first analyzed phosphorylated AMPK (pAMPK) induction by Western blot. Thirty minutes after exposure to A $\beta 42$, pAMPK was significantly upregulated (Figure 3A). Next, we examined the modulation of SIRT1 levels in response to A $\beta 42$ and the effects of pharmacological AMPK blockade with BML-275. Western blot showed that within $6 \mathrm{~h}$, SIRT1 content was increased, an effect slightly but significantly reduced by BML-275 ( $2 \mu \mathrm{M}$; Figure 3B). After $72 \mathrm{~h}$, SIRT1 returned to control levels in microglia exposed to $A \beta 42$ alone (Figure $3 C$ ). Again, we tested the effects of melatonin $(1 \mu \mathrm{M})$ in combination with $\mathrm{A} \beta 42$. As shown in Figure $3 \mathrm{C}$, in these conditions SIRT1 levels remained significantly higher than control or $\mathrm{A} \beta 42$-treated cells. This effect was sensitive to MT receptors antagonist luzindole $(25 \mu \mathrm{M}$; Figure $3 \mathrm{C})$. 
A.
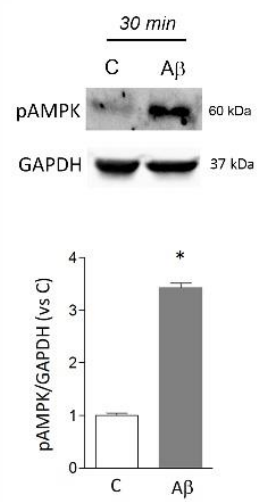

B.
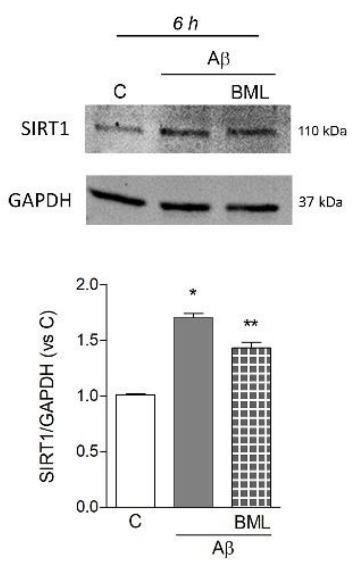

C.
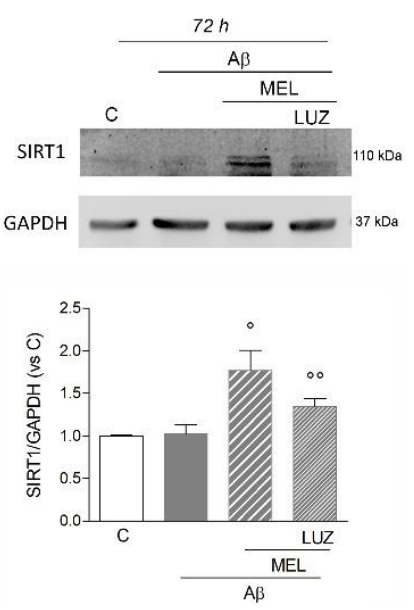

Figure 3. Involvement of pAMPK and time-course of SIRT1 expression in HMC 3 cells upon A $\beta 42$ exposure. Intracellular content of $\operatorname{pAMPK}(\mathbf{A})$ and SIRT1 $(\mathbf{B}, \mathbf{C})$ was evaluated by Western blot analysis at the time points indicated. Cells were exposed to either $\mathrm{A} \beta 42(0.2 \mu \mathrm{M})$ alone or in combination with AMPK inhibitor BML-275 (BML, $2 \mu \mathrm{M}$; B), with melatonin (MEL, $1 \mu \mathrm{M}$; C) or with MEL+luzindole (LUZ, $25 \mu \mathrm{M}$; C). Representative blots are shown. Results are the mean \pm SEM of $3-5$ independent experiments. ${ }^{*} p<0.05$ vs. $\mathrm{C}$ by Student's t-test (A), ${ }^{*} p<0.05$ vs. $\mathrm{C},{ }^{* *} p<0.05$ vs. $\mathrm{A} \beta(\mathbf{B}){ }^{\circ} p<0.05$ vs. $\mathrm{C}$ and $\mathrm{A} \beta$, ${ }^{\circ} p<0.05$ vs. A $\beta+$ MEL (C) by one-way ANOVA followed by Newman Keuls test for significance.

In order to analyze the activation of SIRT1, we carried out an enzymatic activity assay and Western analysis of its nuclear localization. The activity assay was selectively performed on SIRT1 immunoprecipitates in order to exclude contribution from other sirtuins. Results confirmed that after $6 \mathrm{~h}$ of exposure to A $\beta 42(0.2 \mu \mathrm{M})$, SIRT1 activity was significantly increased compared to control (Figure 4A). In agreement, analysis of the subcellular localization of upregulated SIRT1 showed an increase in the nuclear fraction (Figure 4B) and a parallel reduction in the cytosolic fraction (Figure 4C).

A.

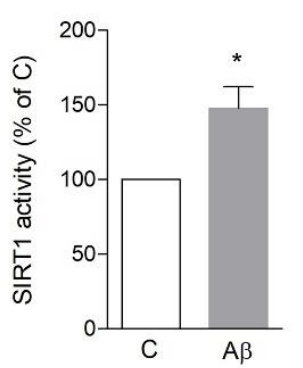

B.

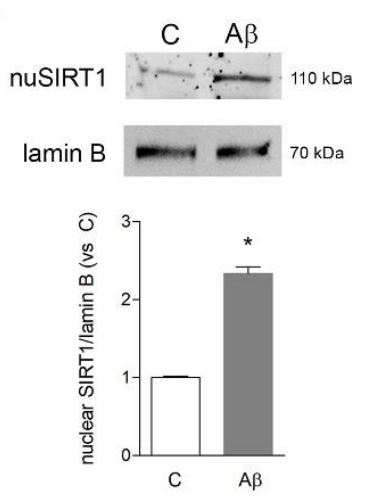

C.
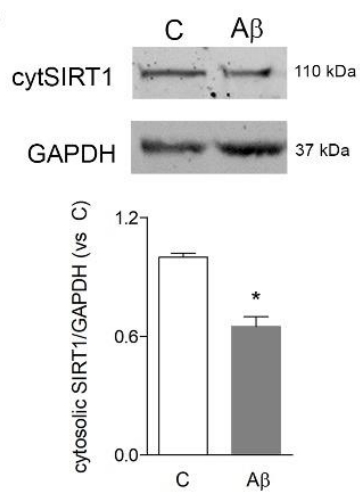

Figure 4. Activity and subcellular localization of SIRT1 in HMC3 cells upon A $\beta 42$ exposure. Cells were treated for $6 \mathrm{~h}$ with $\mathrm{A} \beta 42(0.2 \mu \mathrm{M})$. SIRT1 enzymatic activity was evaluated in lysates immunoprecipitated for SIRT1 (A). Nuclear (B) and cytosolic (C) expression of SIRT1 were investigated by Western blot analysis on purified fractions. Representative blots are shown. Results are the mean \pm SEM of three independent experiments. ${ }^{*} p<0.05$ vs. C by Student's $t$-test for significance.

To further strengthen this result and monitor the sub-cellular localization of SIRT1 in time, cells were immunostained and counted for nuclear SIRT1 positivity. Representative images of SIRT1-labeled cells (green) counterstained with DAPI (blue) are reported in Figure 5A-C. After $6 \mathrm{~h}$ of exposure to A $\beta 42$ alone, the population of nuclear SIRT1positive cells was increased by $108 \%$ over the control (Figure 5D). When in combination 
with melatonin, $A \beta$ induced a significantly more pronounced increase $(165 \%$ over the control; Figure 5D). With A 342 alone, this effect was progressively reduced at $24 \mathrm{~h}(26.7 \%$ over the control; Figure 5D) and disappeared at $72 \mathrm{~h}$ ( $-5 \%$ vs. control; Figure 5D), but remained higher when in combination with melatonin ( $+128 \%$ vs. control at $24 \mathrm{~h}$ and $+27 \%$ vs. control at $72 \mathrm{~h}$; Figure 5D). Overall, these results confirm that SIRT1 is shortly but transiently upregulated by microglia in response to $\mathrm{A} \beta 42$ and that melatonin is able to potentiate and prolong this effect.

A.

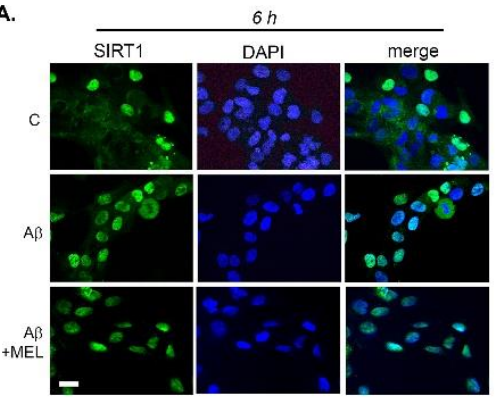

c.

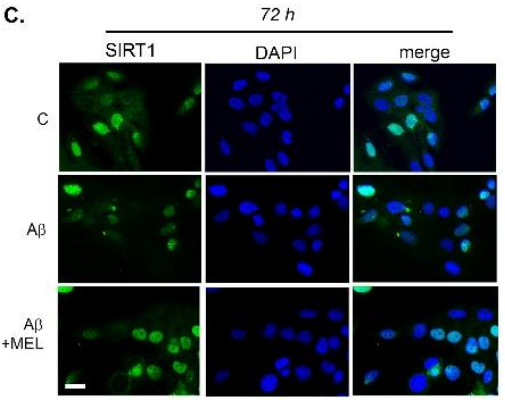

B.
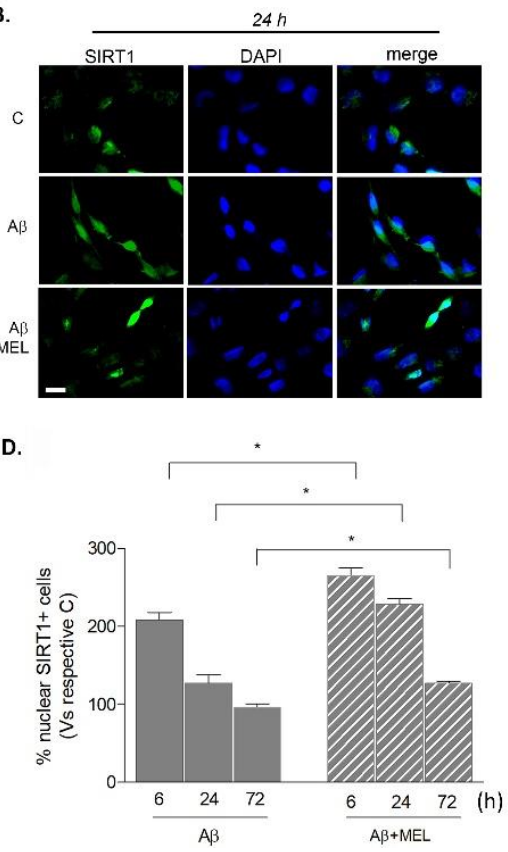

Figure 5. Time course of SIRT1 nuclear localization in HMC3 cells upon A $\beta 42$ exposure. Cells were treated with $0.2 \mu \mathrm{M}$ of $\mathrm{A} \beta 42$ alone or in combination with $1 \mu \mathrm{M}$ melatonin (MEL) for 6, 24, or $72 \mathrm{~h}$. In panels $(\mathrm{A}-\mathrm{C})$, representative images of immunostaining for SIRT1 (green) and nuclear counterstaining with DAPI (blue). Scale bar $=40 \mu \mathrm{m}$. In panel (D), graph reporting the percentage of nuclear SIRT1-positive cells over total SIRT1-positive cells, each vs. respective control, set as 100\%. Results are the mean \pm SEM of $3-5$ independent experiments. ${ }^{*} p<0.05$ vs. treatment with A $\beta$ alone at corresponding time points (two-way ANOVA followed by Newman-Keuls test for significance; treatment vs. time).

\subsection{Melatonin Reduces Microglial NF-kB Expression Induced by Prolonged A $\beta 42$ Exposure}

We next focused on NF-kB, a well-known target of SIRT1, with a crucial role in microglial pro-inflammatory activation. Western blot analysis on nuclear fractions confirmed an increase of NF-kB p65 after a 72 h-exposure to A $\beta 42$ (Figure 6A). Addition of melatonin $(1 \mu \mathrm{M})$ prevented this effect in an EX527- $(5 \mu \mathrm{M})$ and luzindole- $(25 \mu \mathrm{M})$ dependent fashion (Figure 6A). Since SIRT1 can directly inactivate NF-kB by deacetylation at lysine 310 (Lys310), immunostaining of acetylated NF-kB p65 was performed (green; Figure 6B). Results confirmed an increase of nuclear acetylated NF-kB-positive cells following A $\beta 42$ exposure for $72 \mathrm{~h}$. This effect was counteracted by melatonin but reappeared when cells were exposed to $A \beta 42+$ melatonin under a blockade of SIRT1 by EX527 (Figure 6B). The long-term effects of $A \beta 42$ were also accompanied by slight morphological changes, as visualized by staining with fluorescent dye FM 1-43 (5 $\mathrm{MM}$ for $15 \mathrm{~min}$ ). As shown in Figure 6C, HMC3 cells exhibited an elongated, bipolar phenotype upon exposure to A $\beta 42$ $(0.2 \mu \mathrm{M})$, which was partially reversed by treatment with melatonin. 
A.

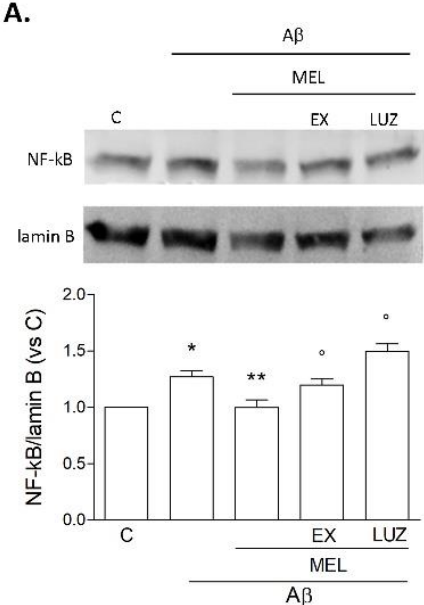

B.

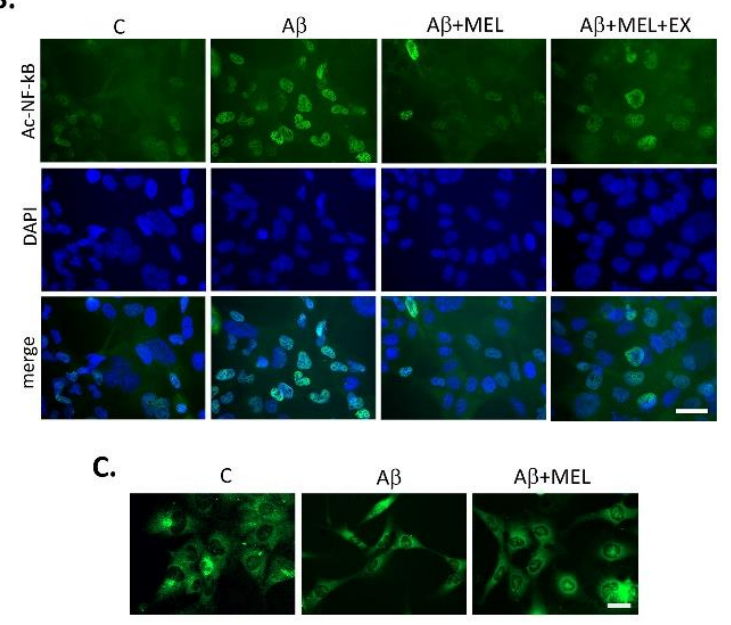

Figure 6. Pro-inflammatory switch of $\mathrm{HMC} 3$ cells upon prolonged A $\beta 42$ exposure. Cells were treated for $72 \mathrm{~h}$ with $\mathrm{A} \beta 42$ alone $(0.2 \mu \mathrm{M})$, in combination with melatonin (MEL, $1 \mu \mathrm{M}), \mathrm{MEL}+\mathrm{EX} 527$ (EX; $5 \mu \mathrm{M}$ ), or MEL+luzindole (LUZ; $25 \mu \mathrm{M}$ ). In (A), Western blot of NF-kB p65 on nuclear fractions. Results are the mean \pm SEM of three independent experiments, and a representative blot is shown. ${ }^{*} p<0.05$ vs. $C,{ }^{* *} p<0.05$ vs. A $\beta,{ }^{\circ} p<0.05$ vs. A $\beta+$ MEL by one-way ANOVA followed by NewmanKeuls test for significance. In (B), representative images of immunostaining for acetyl-Lys310-NF-kB p65 (green) with DAPI counterstaining (blue; scale bar $=40 \mu \mathrm{m})$. In $(\mathbf{C})$, morphological appearance of cells stained with fluorescent dye FM 1-43 (5 $\mu \mathrm{M}$ for $15 \mathrm{~min}$; scale bar $=50 \mu \mathrm{m})$.

\section{Discussion}

Microglia are the resident immune cells in the brain and play a crucial role of surveillance against micro-environmental changes that could pose a threat to brain homeostasis. Microglial activation is finely balanced between pro- and anti-inflammatory phenotypes that act in concert to restore homeostasis through self-limited inflammatory events. However, this balance can be disrupted under chronic toxicity, leading to a switch from protective to detrimental [45-48]. This has been proposed to occur also in $A D$, where progressive accumulation of $A \beta 42$ oligomers, over a time span of up to two decades, slowly but relentlessly leads to progressive cellular distress and chronic toxicity. This in time will push microglia towards an inflammation-sustaining phenotype [5,49-51].

The focus on microglial contribution in AD has been especially, though mainly unsuccessfully, aimed at contrasting inflammation [52,53]. However, targeting microglia to enhance their initial protective features, rather than entirely turning off their activation, appears as an appealing strategy. To this end, the very initial responses of microglia to $A \beta$ still need to be fully characterized.

Our present study moves from our previous work, where we established in vitro models of slow-developing neuronal damage using low concentrations of oligomeric $A \beta[11,54]$. This allowed us to show that early $A \beta$-induced microglial BDNF was the mediator of an early compensatory and protective response against $A \beta$ toxicity in neuronal cells $[11,54]$. On these bases, the next step was to study the time course and the mechanisms underlying $\mathrm{A} \beta$-induced BDNF increase in microglia. For our purposes, we were now able to use microglia of human origin, the HMC3 cell line [55]. This appears relevant due to the different responses between murine and human microglia, as recently pointed out [56]. Notably, the early increase in BDNF and the time-dependent fluctuations in anti- and pro-inflammatory gene expression confirmed that our model, based on low A $\beta 42$ as a light noxious stimulus, well recapitulated the dual microglial activation and the intrinsic decline of the initial neurotrophic response. In agreement, BDNF reduction has been largely linked to cognitive decline in AD patients [57-59] and preclinical in vivo models, where its administration proved to be neuro- and synapto-protective [60-62]. In vitro models 
provided concordant observations [63-65]. Notably, it was also shown that aging itself can cause a decline in microglial BDNF, which correlates with a pro-inflammatory switch [66].

Since the ability to support BDNF-producing, protective microglia entails the identification of an appropriate target, we here contemplated a role for SIRT1. In order to fully characterize the involvement of SIRT1 in our model and to exclude the contribution of other cellular sirtuins to the measured deacetylase activity, an in vitro activity assay was firstly carried out using SIRT1-immunoprecipitated lysates. Furthermore, SIRT1 nuclear localization was evaluated as an index of enzyme activation. Evidence from different cell types shows in fact that SIRT1 can shuttle between the nucleus and cytoplasm, exerting differential functions $[67,68]$. It has been pointed out that SIRT1 activity may be hampered depending on local $\mathrm{NAD}^{+}$availability [69]. However, this was not the case in our conditions, as shown by the inhibitory effects of EX527. Finally, because SIRT1 activity has been reported to be interconnected with the activation of the AMPK pathway [70,71], we confirmed AMPK involvement both by looking at its direct induction by A $\beta 42$, and by evidencing the effects of its pharmacological blockade on SIRT1 expression. The choice to focus on SIRT1 was based on its established neuroprotective role, particularly relevant against aging and age-related diseases. SIRT1 has multiple beneficial actions in the central nervous system [72], including modulation of synaptic plasticity, learning, and memory [73,74], anti-apoptotic activity, and antioxidant and anti-inflammatory properties [75]. Deacetylation of key transcription factors such as forkhead box O3 (FOXO3), peroxisome proliferator-activated receptor $\gamma(\mathrm{PPAR} \gamma)$, and NF-kB appear mainly involved in these effects [39,75-77]. Also in AD animal models, activation or overexpression of SIRT1 was linked to neuroprotection and improved cognitive function [78-80], whereas cognitive deficits in SIRT1 knockout mice were aggravated (Bonda et al., 2011). Interestingly, in AD patients, levels of SIRT1 appeared reduced in the serum [81], hippocampus [82], and cortex [24] and inversely correlated with neuropathological changes [23]. These data are supported by in vitro studies showing that SIRT1 directly affected A $\beta$ production in neurons [83], promoted $A \beta$ clearance in astrocytes [84], and inhibited inflammatory signaling in microglia [22].

Our results showed that in microglia, SIRT1 peaked early, but transiently, after A $\beta 42$ exposure, mediating an initial BDNF-sustained neurotrophic response. In an attempt to prolong the beneficial microglial polarization, we considered as a potential candidate melatonin, a safe molecule that easily crosses the blood-brain barrier $[31,85]$. Indeed, melatonin in combination with $\mathrm{A} \beta$ prolonged the BDNF-producing state of human microglial cells, an effect majorly dependent on the induction of SIRT1 and on surface signaling through MT1/MT2 receptors. At the same time, melatonin prevented nuclear induction of proinflammatory transcription factor NF-kB and, importantly, attenuated its acetylation at Lys310. This is consistent with the reported ability of SIRT1 to inactivate NF-kB by the removal of the acetylic group in Lys 310 [86], which is required for NF-kB full transcriptional activity on target promoters [87]. Indeed, NF-kB inactivation prevents the microglia pro-inflammatory switch and appears relevant for neuroprotection in AD, as previously shown $[21,22,88]$. In our hands, the A $\beta$-induced microglial switch correlated with a slight trend towards a more elongated cell morphology, which melatonin was able to prevent. Data on morphological changes connected to pro-inflammatory activation of the HMC3 cell line are currently scarce and somewhat discordant. In one study, HMC3 cells appeared elongated and bipolar following stimulation with IFN $\gamma+\operatorname{IL} 1 \beta$ for $24 \mathrm{~h}$ [89]. In another report, activation with a high concentration of $\mathrm{A} \beta 42(5 \mu \mathrm{M})$ for $24 \mathrm{~h}$ corresponded to the acquisition of an amoeboid shape [90].

Overall, our results on melatonin's effects are in agreement with its reported multiple beneficial actions that go well beyond a mere regulation of circadian rhythms. The compound is in fact endowed with anti-inflammatory, antioxidant, and neuroprotective activity against a number of neurodegenerative conditions that share neuroinflammatory features [35,91], including Parkinson's disease [92], hypoxia [29,93], amyotrophic lateral sclerosis [94], traumatic brain injury, spinal cord injury [95], and neuropsychiatric disor- 
ders [96]. A role for melatonin has convincingly emerged also in AD, where an inverse correlation between melatonin levels and disease progression has been reported in patients, along with sleep-wake cycle disturbances $[43,97]$. This could be indicative of a potential loss of endogenous protection when melatonin levels are reduced. Preclinical studies on $\mathrm{AD}$ transgenic mice models confirmed the rescue of cognitive functions by melatonin administration, also in association with AD-approved symptomatic drug memantine [98-101]. However, molecular mechanisms involved in melatonin-mediated neuroprotection have been majorly investigated in neurons, whereas studies on glial cells are limited. Melatonin was reported to suppress the hippocampal glial activation induced by A $\beta 25-35$ in rats [102], but, to our knowledge, there are no other detailed studies on glial cells as potential targets for melatonin in $\mathrm{AD}$. We here showed for the first time that the addition of melatonin to $\mathrm{A} \beta$ was efficient in prolonging the peak in SIRT1 and related BDNF expression, maintaining human microglia in an anti-inflammatory state.

\section{Conclusions}

Long before $\mathrm{AD}$ patients enter the clinical phase, attempted protective responses take place at the cellular level that may be important in determining some degree of resilience to neurodegeneration $[103,104]$. Among these, microglial protective activation seems to play a key role. In the present study, we demonstrated that following a subtle challenge with $A \beta$, human microglial cells upregulate BDNF synthesis and release, via induction of deacetylase SIRT1. This effect is accompanied by anti-inflammatory features, but is only transient. We here show that the addition of melatonin can maintain high SIRT1/BDNF levels in the presence of $A \beta$ for a prolonged time (Figure 7). Our study thus identifies microglial SIRT1 as a potential target in AD and highlights a therapeutic potential for melatonin as a SIRT1/BDNF inducer in microglial cells.

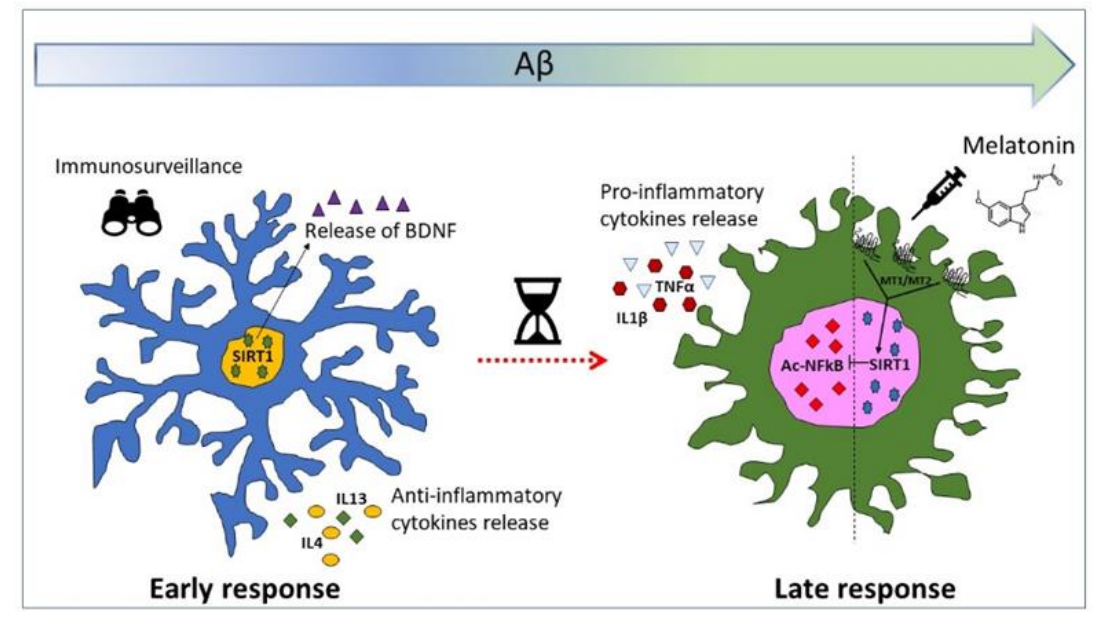

Figure 7. Dual response of microglia to $\mathrm{A} \beta$ challenge.

Author Contributions: Conceptualization: S.M. and M.A.S.; data curation: G.I.C., S.M., and M.A.S.; formal analysis, G.I.C., S.F.S., and S.M.; funding acquisition: M.A.S.; investigation: G.I.C., S.F.S., G.C., and S.M.; supervision: S.M. and M.A.S.; writing-original draft: G.I.C., S.M., and M.A.S. All authors have read and agreed to the published version of the manuscript.

Funding: This research was funded by PRIN2017 from the Italian Ministry of University and Research, grant number 2017XZ7A37_004.

Acknowledgments: The authors wish to acknowledge the support of Depofarma S.p.A., Italy.

Conflicts of Interest: The authors declare no conflict of interest. 


\section{References}

1. Holtzman, D.M.; Morris, J.C.; Goate, A.M. Alzheimer's disease: The challenge of the second century. Sci. Transl. Med. 2011, 3, 77sr71. [CrossRef]

2. Dubois, B.; Hampel, H.; Feldman, H.H.; Scheltens, P.; Aisen, P.; Andrieu, S.; Bakardjian, H.; Benali, H.; Bertram, L.; Blennow, K.; et al. Preclinical Alzheimer's disease: Definition, natural history, and diagnostic criteria. Alzheimer's Dement. J. Alzheimer's Assoc. 2016, 12, 292-323. [CrossRef]

3. Cummings, J.; Lee, G.; Ritter, A.; Sabbagh, M.; Zhong, K. Alzheimer's disease drug development pipeline: 2020. Alzheimer's Dement. 2020, 6, e12050. [CrossRef]

4. Polanco, J.C.; Li, C.; Bodea, L.G.; Martinez-Marmol, R.; Meunier, F.A.; Gotz, J. Amyloid-beta and tau complexity-Towards improved biomarkers and targeted therapies. Nat. Rev. Neurol. 2018, 14, 22-39. [CrossRef]

5. Selkoe, D.J.; Hardy, J. The amyloid hypothesis of Alzheimer's disease at 25 years. EMBO Mol. Med. 2016, 8, 595-608. [CrossRef] [PubMed]

6. Pereira, J.B.; Janelidze, S.; Ossenkoppele, R.; Kvartsberg, H.; Brinkmalm, A.; Mattsson-Carlgren, N.; Stomrud, E.; Smith, R.; Zetterberg, H.; Blennow, K.; et al. Untangling the association of amyloid-beta and tau with synaptic and axonal loss in Alzheimer's disease. Brain J. Neurol. 2020. [CrossRef]

7. Gao, Y.; Tan, L.; Yu, J.T.; Tan, L. Tau in Alzheimer's disease: Mechanisms and therapeutic strategies. Curr. Alzheimer Res. 2018, 15, 283-300. [CrossRef]

8. Caruso, G.; Spampinato, S.F.; Cardaci, V.; Caraci, F.; Sortino, M.A.; Merlo, S. Beta-amyloid and oxidative stress: Perspectives in drug development. Curr. Pharm. Des. 2019, 25, 4771-4781. [CrossRef] [PubMed]

9. Zuroff, L.; Daley, D.; Black, K.L.; Koronyo-Hamaoui, M. Clearance of cerebral Abeta in Alzheimer's disease: Reassessing the role of microglia and monocytes. Cell. Mol. Life Sci. CMLS 2017, 74, 2167-2201. [CrossRef] [PubMed]

10. Merlo, S.; Spampinato, S.F.; Caruso, G.I.; Sortino, M.A. The ambiguous role of microglia in abeta toxicity: Chances for therapeutic intervention. Curr. Neuropharmacol. 2020, 18, 446-455. [CrossRef]

11. Merlo, S.; Spampinato, S.F.; Beneventano, M.; Sortino, M.A. The contribution of microglia to early synaptic compensatory responses that precede beta-amyloid-induced neuronal death. Sci. Rep. 2018, 8, 7297. [CrossRef] [PubMed]

12. Rivest, S. TREM2 enables amyloid beta clearance by microglia. Cell Res. 2015, 25, 535-536. [CrossRef] [PubMed]

13. Whittington, R.A.; Planel, E.; Terrando, N. Impaired resolution of inflammation in Alzheimer's disease: A review. Front. Immunol. 2017, 8, 1464. [CrossRef] [PubMed]

14. Lima Giacobbo, B.; Doorduin, J.; Klein, H.C.; Dierckx, R.; Bromberg, E.; de Vries, E.F.J. Brain-derived neurotrophic factor in brain disorders: Focus on neuroinflammation. Mol. Neurobiol. 2019, 56, 3295-3312. [CrossRef]

15. Deczkowska, A.; Keren-Shaul, H.; Weiner, A.; Colonna, M.; Schwartz, M.; Amit, I. Disease-associated microglia: A universal immune sensor of neurodegeneration. Cell 2018, 173, 1073-1081. [CrossRef] [PubMed]

16. Rangaraju, S.; Dammer, E.B.; Raza, S.A.; Rathakrishnan, P.; Xiao, H.; Gao, T.; Duong, D.M.; Pennington, M.W.; Lah, J.J.; Seyfried, N.T.; et al. Identification and therapeutic modulation of a pro-inflammatory subset of disease-associated-microglia in Alzheimer's disease. Mol. Neurodegener. 2018, 13, 24. [CrossRef] [PubMed]

17. Xu, J.; Jackson, C.W.; Khoury, N.; Escobar, I.; Perez-Pinzon, M.A. Brain SIRT1 mediates metabolic homeostasis and neuroprotection. Front. Endocrinol. 2018, 9, 702. [CrossRef]

18. Wong, S.Y.; Tang, B.L. SIRT1 as a therapeutic target for Alzheimer's disease. Rev. Neurosci. 2016, 27, 813-825. [CrossRef]

19. Herskovits, A.Z.; Guarente, L. Sirtuin deacetylases in neurodegenerative diseases of aging. Cell Res. 2013, 23, 746-758. [CrossRef]

20. Zhang, F.; Wang, S.; Gan, L.; Vosler, P.S.; Gao, Y.; Zigmond, M.J.; Chen, J. Protective effects and mechanisms of sirtuins in the nervous system. Prog. Neurobiol. 2011, 95, 373-395. [CrossRef]

21. Kauppinen, A.; Suuronen, T.; Ojala, J.; Kaarniranta, K.; Salminen, A. Antagonistic crosstalk between NF-kappaB and SIRT1 in the regulation of inflammation and metabolic disorders. Cell. Signal. 2013, 25, 1939-1948. [CrossRef]

22. Chen, J.; Zhou, Y.; Mueller-Steiner, S.; Chen, L.-F.; Kwon, H.; Yi, S.; Mucke, L.; Gan, L. SIRT1 Protects against microglia-dependent amyloid- $\beta$ toxicity through inhibiting NF- $\mathrm{kB}$ signaling. J. Biol. Chem. 2005, 280, 40364-40374. [CrossRef]

23. Lutz, M.I.; Milenkovic, I.; Regelsberger, G.; Kovacs, G.G. Distinct patterns of sirtuin expression during progression of Alzheimer's disease. Neuromolecular Med. 2014, 16, 405-414. [CrossRef]

24. Julien, C.; Tremblay, C.; Emond, V.; Lebbadi, M.; Salem, N., Jr.; Bennett, D.A.; Calon, F. Sirtuin 1 reduction parallels the accumulation of tau in Alzheimer disease. J. Neuropathol. Exp. Neurol. 2009, 68, 48-58. [CrossRef] [PubMed]

25. Lee, H.R.; Shin, H.K.; Park, S.Y.; Kim, H.Y.; Lee, W.S.; Rhim, B.Y.; Hong, K.W.; Kim, C.D. Cilostazol suppresses beta-amyloid production by activating a disintegrin and metalloproteinase 10 via the upregulation of SIRT1-coupled retinoic acid receptor-beta. J. Neurosci. Res. 2014, 92, 1581-1590. [CrossRef]

26. Mahmood, D. Pleiotropic effects of melatonin. Drug Res. 2019, 69, 65-74. [CrossRef] [PubMed]

27. Vincent, B. Protective roles of melatonin against the amyloid-dependent development of Alzheimer's disease: A critical review. Pharmacol. Res. 2018, 134, 223-237. [CrossRef] [PubMed]

28. Mack, J.M.; Schamne, M.G.; Sampaio, T.B.; Pertile, R.A.; Fernandes, P.A.; Markus, R.P.; Prediger, R.D. Melatoninergic system in Parkinson's disease: From neuroprotection to the management of motor and nonmotor symptoms. Oxidative Med. Cell. Longev. 2016, 2016, 3472032. [CrossRef] 
29. Paprocka, J.; Kijonka, M.; Rzepka, B.; Sokol, M. Melatonin in hypoxic-ischemic brain injury in term and preterm babies. Int. J. Endocrinol. 2019, 2019, 9626715. [CrossRef] [PubMed]

30. Shen, Z.; Zhou, Z.; Gao, S.; Guo, Y.; Gao, K.; Wang, H.; Dang, X. melatonin inhibits neural cell apoptosis and promotes locomotor recovery via activation of the Wnt/beta-catenin signaling pathway after spinal cord injury. Neurochem. Res. 2017, 42, 2336-2343. [CrossRef] [PubMed]

31. Andersen, L.P.; Gogenur, I.; Rosenberg, J.; Reiter, R.J. The safety of melatonin in humans. Clin. Drug Investig. 2016, 36, 169-175. [CrossRef] [PubMed]

32. Shukla, M.; Chinchalongporn, V.; Govitrapong, P.; Reiter, R.J. The role of melatonin in targeting cell signaling pathways in neurodegeneration. Ann. N. Y. Acad. Sci. 2019, 1443, 75-96. [CrossRef]

33. Emet, M.; Ozcan, H.; Ozel, L.; Yayla, M.; Halici, Z.; Hacimuftuoglu, A. A review of melatonin, its receptors and drugs. Eurasian J. Med. 2016, 48, 135-141. [CrossRef]

34. Ng, K.Y.; Leong, M.K.; Liang, H.; Paxinos, G. Melatonin receptors: Distribution in mammalian brain and their respective putative functions. Brain Struct. Funct. 2017, 222, 2921-2939. [CrossRef]

35. Alghamdi, B.S. The neuroprotective role of melatonin in neurological disorders. J. Neurosci. Res. 2018, 96, 1136-1149. [CrossRef]

36. Boutin, J.A.; Ferry, G. Is there sufficient evidence that the melatonin binding site MT3 Is quinone reductase 2? J. Pharmacol. Exp. Ther. 2019, 368, 59-65. [CrossRef] [PubMed]

37. Smirnov, A.N. Nuclear melatonin receptors. Biochemistry 2001, 66, 19-26. [CrossRef]

38. Reiter, R.J.; Paredes, S.D.; Manchester, L.C.; Tan, D.X. Reducing oxidative/nitrosative stress: A newly-discovered genre for melatonin. Crit. Rev. Biochem. Mol. Biol. 2009, 44, 175-200. [CrossRef]

39. Chen, C.; Zhou, M.; Ge, Y.; Wang, X. SIRT1 and aging related signaling pathways. Mech. Ageing Dev. 2020, 187, 111215. [CrossRef]

40. Li, Y.; Zhang, J.; Wan, J.; Liu, A.; Sun, J. Melatonin regulates Abeta production/clearance balance and Abeta neurotoxicity: A potential therapeutic molecule for Alzheimer's disease. Biomed. Pharmacother. 2020, 132, 110887. [CrossRef]

41. Shi, Y.; Fang, Y.Y.; Wei, Y.P.; Jiang, Q.; Zeng, P.; Tang, N.; Lu, Y.; Tian, Q. Melatonin in synaptic impairments of Alzheimer's Disease. J. Alzheimer's Dis. 2018, 63, 911-926. [CrossRef]

42. Mihardja, M.; Roy, J.; Wong, K.Y.; Aquili, L.; Heng, B.C.; Chan, Y.S.; Fung, M.L.; Lim, L.W. Therapeutic potential of neurogenesis and melatonin regulation in Alzheimer's disease. Ann. N. Y. Acad. Sci. 2020, 1478, 43-62. [CrossRef]

43. Wade, A.G.; Farmer, M.; Harari, G.; Fund, N.; Laudon, M.; Nir, T.; Frydman-Marom, A.; Zisapel, N. Add-on prolonged-release melatonin for cognitive function and sleep in mild to moderate Alzheimer's disease: A 6-month, randomized, placebo-controlled, multicenter trial. Clin. Interv. Aging 2014, 9, 947-961. [CrossRef]

44. Merlo, S.; Sortino, M.A. Estrogen activates matrix metalloproteinases-2 and -9 to increase beta amyloid degradation. Mol. Cell. Neurosci. 2012, 49, 423-429. [CrossRef]

45. Cianciulli, A.; Porro, C.; Calvello, R.; Trotta, T.; Lofrumento, D.D.; Panaro, M.A. Microglia mediated neuroinflammation: Focus on PI3K modulation. Biomolecules 2020, 10, 135. [CrossRef]

46. Du, L.; Zhang, Y.; Chen, Y.; Zhu, J.; Yang, Y.; Zhang, H.L. role of microglia in neurological disorders and their potentials as a therapeutic target. Mol. Neurobiol. 2017, 54, 7567-7584. [CrossRef]

47. Gupta, N.; Shyamasundar, S.; Patnala, R.; Karthikeyan, A.; Arumugam, T.V.; Ling, E.A.; Dheen, S.T. Recent progress in therapeutic strategies for microglia-mediated neuroinflammation in neuropathologies. Expert Opin. Ther. Targets 2018, 22, 765-781. [CrossRef] [PubMed]

48. Hu, X.; Leak, R.K.; Shi, Y.; Suenaga, J.; Gao, Y.; Zheng, P.; Chen, J. Microglial and macrophage polarization-new prospects for brain repair. Nat. Rev. Neurol. 2015, 11, 56-64. [CrossRef]

49. Hamelin, L.; Lagarde, J.; Dorothee, G.; Leroy, C.; Labit, M.; Comley, R.A.; de Souza, L.C.; Corne, H.; Dauphinot, L.; Bertoux, M.; et al. Early and protective microglial activation in Alzheimer's disease: A prospective study using 18F-DPA-714 PET imaging. Brain J. Neurol. 2016, 139, 1252-1264. [CrossRef] [PubMed]

50. Fan, Z.; Brooks, D.J.; Okello, A.; Edison, P. An early and late peak in microglial activation in Alzheimer's disease trajectory. Brain J. Neurol. 2017, 140, 792-803. [CrossRef]

51. Shen, Z.; Bao, X.; Wang, R. Clinical PET imaging of microglial activation: Implications for microglial therapeutics in Alzheimer's disease. Front. Aging Neurosci. 2018, 10, 314. [CrossRef]

52. Ozben, T.; Ozben, S. Neuro-inflammation and anti-inflammatory treatment options for Alzheimer's disease. Clin. Biochem. 2019, 72, 87-89. [CrossRef] [PubMed]

53. Gyengesi, E.; Munch, G. In search of an anti-inflammatory drug for Alzheimer disease. Nat. Rev. Neurol. 2020, 16, 131-132. [CrossRef]

54. Merlo, S.; Spampinato, S.F.; Capani, F.; Sortino, M.A. Early beta-Amyloid-induced synaptic dysfunction is counteracted by estrogen in organotypic hippocampal cultures. Curr. Alzheimer Res. 2016, 13, 631-640. [CrossRef]

55. Dello Russo, C.; Cappoli, N.; Coletta, I.; Mezzogori, D.; Paciello, F.; Pozzoli, G.; Navarra, P.; Battaglia, A. The human microglial HMC3 cell line: Where do we stand? A systematic literature review. J. Neuroinflammation 2018, 15, 259. [CrossRef]

56. Smith, A.M.; Dragunow, M. The human side of microglia. Trends Neurosci. 2014, 37, 125-135. [CrossRef] [PubMed]

57. Ng, T.K.S.; Ho, C.S.H.; Tam, W.W.S.; Kua, E.H.; Ho, R.C. decreased serum brain-derived neurotrophic factor (BDNF) levels in patients with Alzheimer's disease (AD): A systematic review and meta-analysis. Int. J. Mol. Sci. 2019, 20, 257. [CrossRef] 
58. Laske, C.; Stellos, K.; Hoffmann, N.; Stransky, E.; Straten, G.; Eschweiler, G.W.; Leyhe, T. Higher BDNF serum levels predict slower cognitive decline in Alzheimer's disease patients. Int. J. Neuropsychopharmacol. 2011, 14, 399-404. [CrossRef]

59. Laske, C.; Stransky, E.; Leyhe, T.; Eschweiler, G.W.; Wittorf, A.; Richartz, E.; Bartels, M.; Buchkremer, G.; Schott, K. Stagedependent BDNF serum concentrations in Alzheimer's disease. J. Neural Transm. 2006, 113, 1217-1224. [CrossRef]

60. Lee, S.T.; Chu, K.; Jung, K.H.; Kim, J.H.; Huh, J.Y.; Yoon, H.; Park, D.K.; Lim, J.Y.; Kim, J.M.; Jeon, D.; et al. miR-206 regulates brain-derived neurotrophic factor in Alzheimer disease model. Ann. Neurol. 2012, 72, 269-277. [CrossRef]

61. Iwasaki, Y.; Negishi, T.; Inoue, M.; Tashiro, T.; Tabira, T.; Kimura, N. Sendai virus vector-mediated brain-derived neurotrophic factor expression ameliorates memory deficits and synaptic degeneration in a transgenic mouse model of Alzheimer's disease. $J$. Neurosci. Res. 2012, 90, 981-989. [CrossRef]

62. Nagahara, A.H.; Merrill, D.A.; Coppola, G.; Tsukada, S.; Schroeder, B.E.; Shaked, G.M.; Wang, L.; Blesch, A.; Kim, A.; Conner, J.M.; et al. Neuroprotective effects of brain-derived neurotrophic factor in rodent and primate models of Alzheimer's disease. Nat. Med. 2009, 15, 331-337. [CrossRef] [PubMed]

63. Tagai, N.; Tanaka, A.; Sato, A.; Uchiumi, F.; Tanuma, S.I. low levels of brain-derived neurotrophic factor trigger self-aggregated amyloid beta-induced neuronal cell death in an alzheimer's cell model. Biol. Pharm. Bull. 2020, 43, 1073-1080. [CrossRef]

64. Mitroshina, E.V.; Yarkov, R.S.; Mishchenko, T.A.; Krut, V.G.; Gavrish, M.S.; Epifanova, E.A.; Babaev, A.A.; Vedunova, M.V. Brain-Derived Neurotrophic Factor (BDNF) preserves the functional integrity of neural networks in the beta-amyloidopathy model in vitro. Front. Cell Dev. Biol. 2020, 8, 582. [CrossRef]

65. Arancibia, S.; Silhol, M.; Mouliere, F.; Meffre, J.; Hollinger, I.; Maurice, T.; Tapia-Arancibia, L. Protective effect of BDNF against beta-amyloid induced neurotoxicity in vitro and in vivo in rats. Neurobiol. Dis. 2008, 31, 316-326. [CrossRef] [PubMed]

66. Wu, S.Y.; Pan, B.S.; Tsai, S.F.; Chiang, Y.T.; Huang, B.M.; Mo, F.E.; Kuo, Y.M. BDNF reverses aging-related microglial activation. J. Neuroinflammation 2020, 17, 210. [CrossRef]

67. Hisahara, S.; Chiba, S.; Matsumoto, H.; Tanno, M.; Yagi, H.; Shimohama, S.; Sato, M.; Horio, Y. Histone deacetylase SIRT1 modulates neuronal differentiation by its nuclear translocation. Proc. Natl. Acad. Sci. USA 2008, 105, 15599-15604. [CrossRef] [PubMed]

68. Tanno, M.; Sakamoto, J.; Miura, T.; Shimamoto, K.; Horio, Y. Nucleocytoplasmic shuttling of the NAD+-dependent histone deacetylase SIRT1. J. Biol. Chem. 2007, 282, 6823-6832. [CrossRef]

69. Hardeland, R. Aging, melatonin, and the pro- and anti-inflammatory networks. Int. J. Mol. Sci. 2019, 20, 1223. [CrossRef]

70. Canto, C.; Gerhart-Hines, Z.; Feige, J.N.; Lagouge, M.; Noriega, L.; Milne, J.C.; Elliott, P.J.; Puigserver, P.; Auwerx, J. AMPK regulates energy expenditure by modulating NAD+ metabolism and SIRT1 activity. Nature 2009, 458, 1056-1060. [CrossRef]

71. Ruderman, N.B.; Xu, X.J.; Nelson, L.; Cacicedo, J.M.; Saha, A.K.; Lan, F.; Ido, Y. AMPK and SIRT1: A long-standing partnership? Am. J. Physiol. Endocrinol. Metab. 2010, 298, E751-E760. [CrossRef] [PubMed]

72. Lee, S.H.; Lee, J.H.; Lee, H.Y.; Min, K.J. Sirtuin signaling in cellular senescence and aging. BMB Rep. 2019, 52, 24-34. [CrossRef]

73. Michan, S.; Li, Y.; Chou, M.M.; Parrella, E.; Ge, H.; Long, J.M.; Allard, J.S.; Lewis, K.; Miller, M.; Xu, W.; et al. SIRT1 is essential for normal cognitive function and synaptic plasticity. J. Neurosci. 2010, 30, 9695-9707. [CrossRef]

74. Gao, J.; Wang, W.Y.; Mao, Y.W.; Graff, J.; Guan, J.S.; Pan, L.; Mak, G.; Kim, D.; Su, S.C.; Tsai, L.H. A novel pathway regulates memory and plasticity via SIRT1 and miR-134. Nature 2010, 466, 1105-1109. [CrossRef] [PubMed]

75. Bonda, D.J.; Lee, H.G.; Camins, A.; Pallas, M.; Casadesus, G.; Smith, M.A.; Zhu, X. The sirtuin pathway in ageing and Alzheimer disease: Mechanistic and therapeutic considerations. Lancet Neurol. 2011, 10, 275-279. [CrossRef]

76. Brunet, A.; Sweeney, L.B.; Sturgill, J.F.; Chua, K.F.; Greer, P.L.; Lin, Y.; Tran, H.; Ross, S.E.; Mostoslavsky, R.; Cohen, H.Y.; et al. Stress-dependent regulation of FOXO transcription factors by the SIRT1 deacetylase. Science 2004, 303, 2011-2015. [CrossRef]

77. Elibol, B.; Kilic, U. High Levels of SIRT1 expression as a protective mechanism against disease-related conditions. Front. Endocrinol. 2018, 9, 614. [CrossRef]

78. Ng, F.; Wijaya, L.; Tang, B.L. SIRT1 in the brain-Connections with aging-associated disorders and lifespan. Front. Cell. Neurosci. 2015, 9, 64. [CrossRef] [PubMed]

79. Kim, D.; Nguyen, M.D.; Dobbin, M.M.; Fischer, A.; Sananbenesi, F.; Rodgers, J.T.; Delalle, I.; Baur, J.A.; Sui, G.; Armour, S.M.; et al. SIRT1 deacetylase protects against neurodegeneration in models for Alzheimer's disease and amyotrophic lateral sclerosis. EMBO J. 2007, 26, 3169-3179. [CrossRef] [PubMed]

80. Corpas, R.; Revilla, S.; Ursulet, S.; Castro-Freire, M.; Kaliman, P.; Petegnief, V.; Gimenez-Llort, L.; Sarkis, C.; Pallas, M.; Sanfeliu, C. SIRT1 Overexpression in mouse hippocampus induces cognitive enhancement through proteostatic and neurotrophic mechanisms. Mol. Neurobiol. 2017, 54, 5604-5619. [CrossRef]

81. Kumar, R.; Chaterjee, P.; Sharma, P.K.; Singh, A.K.; Gupta, A.; Gill, K.; Tripathi, M.; Dey, A.B.; Dey, S. Sirtuin1: A promising serum protein marker for early detection of Alzheimer's disease. PLoS ONE 2013, 8, e61560. [CrossRef]

82. Pukhalskaia, A.E.; Dyatlova, A.S.; Linkova, N.S.; Kozlov, K.L.; Kvetnaia, T.V.; Koroleva, M.V.; Kvetnoy, I.M. Sirtuins as possible predictors of aging and Alzheimer's disease development: Verification in the hippocampus and saliva. Bull. Exp. Biol. Med. 2020, 169, 821-824. [CrossRef]

83. Marwarha, G.; Raza, S.; Meiers, C.; Ghribi, O. Leptin attenuates BACE1 expression and amyloid-beta genesis via the activation of SIRT1 signaling pathway. Biochim. Biophys. Acta 2014, 1842, 1587-1595. [CrossRef] [PubMed]

84. Li, M.Z.; Zheng, L.J.; Shen, J.; Li, X.Y.; Zhang, Q.; Bai, X.; Wang, Q.S.; Ji, J.G. SIRT1 facilitates amyloid beta peptide degradation by upregulating lysosome number in primary astrocytes. Neural. Regen. Res. 2018, 13, 2005-2013. [CrossRef] [PubMed] 
85. Ferlazzo, N.; Andolina, G.; Cannata, A.; Costanzo, M.G.; Rizzo, V.; Curro, M.; Ientile, R.; Caccamo, D. Is melatonin the cornucopia of the 21st century? Antioxidants 2020, 9, 1088. [CrossRef]

86. Yang, H.; Zhang, W.; Pan, H.; Feldser, H.G.; Lainez, E.; Miller, C.; Leung, S.; Zhong, Z.; Zhao, H.; Sweitzer, S.; et al. SIRT1 activators suppress inflammatory responses through promotion of p65 deacetylation and inhibition of NF-kappaB activity. PLoS ONE 2012, 7, e46364. [CrossRef]

87. Chen, L.F.; Mu, Y.; Greene, W.C. Acetylation of RelA at discrete sites regulates distinct nuclear functions of NF-kappaB. EMBO J. 2002, 21, 6539-6548. [CrossRef] [PubMed]

88. Thawkar, B.S.; Kaur, G. Inhibitors of NF-kappaB and P2X7/NLRP3/Caspase 1 pathway in microglia: Novel therapeutic opportunities in neuroinflammation induced early-stage Alzheimer's disease. J. Neuroimmunol. 2019, 326, 62-74. [CrossRef] [PubMed]

89. Cappoli, N.; Mezzogori, D.; Tabolacci, E.; Coletta, I.; Navarra, P.; Pani, G.; Dello Russo, C. The mTOR kinase inhibitor rapamycin enhances the expression and release of pro-inflammatory cytokine interleukin 6 modulating the activation of human microglial cells. EXCLI J. 2019, 18, 779-798. [CrossRef]

90. Akhter, R.; Shao, Y.; Formica, S.; Khrestian, M.; Bekris, L.M. TREM2 alters the phagocytic, apoptotic and inflammatory response to Abeta42 in HMC3 cells. Mol. Immunol. 2021, 131, 171-179. [CrossRef]

91. Tan, H.Y.; Ng, K.Y.; Koh, R.Y.; Chye, S.M. Pharmacological effects of melatonin as neuroprotectant in rodent model: A review on the current biological evidence. Cell. Mol. Neurobiol. 2020, 40, 25-51. [CrossRef] [PubMed]

92. Singhal, N.K.; Srivastava, G.; Agrawal, S.; Jain, S.K.; Singh, M.P. Melatonin as a neuroprotective agent in the rodent models of Parkinson's disease: Is it all set to irrefutable clinical translation? Mol. Neurobiol. 2012, 45, 186-199. [CrossRef]

93. Merlo, S.; Luaces, J.P.; Spampinato, S.F.; Toro-Urrego, N.; Caruso, G.I.; D’Amico, F.; Capani, F.; Sortino, M.A. SIRT1 mediates melatonin's effects on microglial activation in hypoxia: In vitro and in vivo evidence. Biomolecules 2020, 10, 364. [CrossRef] [PubMed]

94. Bald, E.M.; Nance, C.S.; Schultz, J.L. Melatonin may slow disease progression in amyotrophic lateral sclerosis: Findings from the pooled resource open-access ALS clinic trials database. Muscle Nerve 2021. [CrossRef]

95. Naseem, M.; Parvez, S. Role of melatonin in traumatic brain injury and spinal cord injury. Sci. World J. 2014, 2014, 586270. [CrossRef]

96. Lee, J.G.; Woo, Y.S.; Park, S.W.; Seog, D.H.; Seo, M.K.; Bahk, W.M. The neuroprotective effects of melatonin: Possible role in the pathophysiology of neuropsychiatric disease. Brain Sci. 2019, 9, 285. [CrossRef]

97. Nous, A.; Engelborghs, S.; Smolders, I. Melatonin levels in the Alzheimer's disease continuum: A systematic review. Alzheimer's Res. Ther. 2021, 13, 52. [CrossRef]

98. Labban, S.; Alghamdi, B.S.; Alshehri, F.S.; Kurdi, M. Effects of melatonin and resveratrol on recognition memory and passive avoidance performance in a mouse model of Alzheimer's disease. Behav. Brain. Res. 2021, 402, 113100. [CrossRef] [PubMed]

99. Liu, Y.C.; Hsu, W.L.; Ma, Y.L.; Lee, E.H.Y. Melatonin induction of APP intracellular domain 50 SUMOylation alleviates AD through enhanced transcriptional activation and abeta degradation. Mol. Ther. 2021, 29, 376-395. [CrossRef] [PubMed]

100. Sun, C.; Qiu, X.; Wang, Y.; Liu, J.; Li, Q.; Jiang, H.; Li, S.; Song, C. Long-term oral melatonin alleviates memory deficits, reduces amyloid-beta deposition associated with downregulation of BACE1 and mitophagy in APP/PS1 transgenic mice. Neurosci. Lett. 2020, 735, 135192. [CrossRef]

101. Jurgenson, M.; Zharkovskaja, T.; Noortoots, A.; Morozova, M.; Beniashvili, A.; Zapolski, M.; Zharkovsky, A. Effects of the drug combination memantine and melatonin on impaired memory and brain neuronal deficits in an amyloid-predominant mouse model of Alzheimer's disease. J. Pharm. Pharmacol. 2019, 71, 1695-1705. [CrossRef]

102. Shen, Y.; Zhang, G.; Liu, L.; Xu, S. Suppressive effects of melatonin on amyloid-beta-induced glial activation in rat hippocampus. Arch. Med Res. 2007, 38, 284-290. [CrossRef] [PubMed]

103. De Strooper, B.; Karran, E. The cellular phase of Alzheimer's disease. Cell 2016, 164, 603-615. [CrossRef]

104. Merlo, S.; Spampinato, S.F.; Sortino, M.A. Early compensatory responses against neuronal injury: A new therapeutic window of opportunity for Alzheimer's Disease? CNS Neurosci. Ther. 2019, 25, 5-13. [CrossRef] 